\title{
The (ProB27, ThrB28) human insulin analogue is more potent and more rapidly absorbed from subcutis than human insulin
}

\author{
R Clausen, T G Jørgensen, K H Jørgensen, A H Johnsen ${ }^{1}$, J J Led ${ }^{2}$ and K Josefsen \\ Bartholin Instituttet, Kommunehospitalet, Copenhagen, ${ }^{1}$ Department of Clinical Biochemistry, Rigshospitalet, Copenhagen and ${ }^{2}$ Department of \\ Chemistry, University of Copenhagen, Universitetsparken 5, Dk-Copenhagen Ø, Denmark
}

(Correspondence should be addressed to K Josefsen, Bartholin Instituttet, Kommunehospitalet, 1399 Copenhagen K, Denmark; Email: josefsen@rh.dk)

\begin{abstract}
Objective: To test the physiological properties of human insulin in which the amino acids Thr (B27) and Pro (B28) are interchanged (PT insulin). This was hypothesised to prevent dimerisation and accelerate the absorption from s.c. tissue without altering the affinity for the insulin receptor.

Design: PT insulin was expressed in Pichia pastoris and processed in vitro. The purified compound was used for physiological investigations.

Methods: Receptor binding activity to insulin and IGF receptors was evaluated in a competition assay using iodinated PT insulin and recombinant receptors while growth induction properties were evaluated by thymidine incorporation. Absorption kinetics from pig subcutis was investigated by measuring the disappearance of iodinated PT insulin. The potency was evaluated by measuring the blood glucose lowering activity in mice.

Results: The absorption of PT insulin was accelerated compared with human insulin, although still slower than Asp (B28) insulin. Human and PT insulin had similar affinities for the human insulin receptor $\left(K_{\mathrm{d}}=3.6 \times 10^{-12}\right.$ vs $\left.5.2 \times 10^{-12} \mathrm{~mol} / \mathrm{l}\right)$ while the affinity for the IGF receptor was four times higher for PT insulin than for human insulin $\left(K_{d}=3.4 \times 10^{-8}\right.$ vs $\left.1.3 \times 10^{-7} \mathrm{~mol} / \mathrm{l}\right)$. This resulted in a slightly higher DNA synthesis when assayed in intermediary insulin concentrations. The blood glucose lowering effect in mice exceeded the effect of human insulin (integral 0-60 min: $61.4 \pm 7$ vs $30 \pm 4, n=6, P=0.046)$.

Conclusions: PT insulin is absorbed faster and is more potent than human insulin. Although PT insulin stimulates growth more than human insulin, this will not prevent its use in the clinic, but the main interest will probably focus on investigations to clarify the paradox of full biological activity in connection with the recently described lack of structure in the B-chain.
\end{abstract}

European Journal of Endocrinology 147 227-233

\section{Introduction}

In aqueous solutions, insulin exists as monomers, dimers, tetramers and hexamers, depending on $\mathrm{pH}$, concentration and the presence of zinc ions (1). Generally, insulin formulations used for treatment of insulin dependent diabetes mellitus (IDDM) are hexameric, which results in a slow absorption rate from s.c. tissue because conversion to dimers and monomers must first occur (2). The monomeric insulin molecule is also the active form to bind to the insulin receptor (3). Although vast improvements have been obtained in the treatment of IDDM with altered insulin formulations, rapid-acting insulins, which are needed to avoid the impractical delay in absorption of insulin prior to meals, must be made by changing the insulin itself due to the molecule's polymerisation. Previous work has shown that monomeric insulin is absorbed considerably faster than hexameric insulin (2). Since only a few rapid-acting human insulin analogue preparations are yet available (4), and the clinical experience still limited (3, 6-8), alternative insulin analogues that minimise aggregation are still needed.

Previous structural investigations indicate that dimer formation in human insulin is mainly mediated by the carboxy-terminal end of the B-chain where four hydrogen bonds between Phe (B24) and Tyr (B26) are essential $(9,10)$. One way to disrupt dimerisation is to introduce or move a bulky side chain into the dimerforming surface. This is the likely reason for desB25 human insulin to become monomeric, since deletion of Phe (B25) moves the residue Pro (B28) to position 27 in the B-chain. This causes its hydrophobic side chain to turn away from the surface of the molecule and towards the $\alpha$-helix of the B-chain, resulting in new intramolecular interactions and abolition of the 
intermolecular interactions between monomers (11). Sterically, Pro acts as a large-sized amino acid because it is cyclic and thus it interferes with the peptide backbone.

We hypothesised that interchanging B27 (Thr) and B28 (Pro) would similarly disrupt the intermolecular interactions. Both of these amino acids are involved in stabilising the dimer structure: Thr (B27) makes loose hydrophobic contact to Asn (A21) and Pro (B28) stabilises the structure by hydrophobic contact to Gly (B20), Glu (B21) and Gly (B23) (9). It was expected that the alteration would not affect the receptor binding site (12). The aim of the study was to test this hypothesis.

\section{Materials and methods}

\section{Recombinant DNA}

DNA encoding human genomic insulin (American Tissue Culture Collection, Rockville, MD, USA) was used as a template in two separate PCR reactions to synthesise A- and modified B-chain using high fidelity Pfu polymerase (Stratagene, La Jolla, CA, USA) with the primers: A1: 5'tacccaacaagaccaagagaggcattgtggaacaatga, A2: 3'acctcttgatgacgttgatccttaagcg, B1: 5'ccgccgctcgagaaaagatttgtgaaccaacaccg, B2 3'cccttgctccgaagaagatggggtgtttctggttc. The chains were ligated in a third PCR reaction, digested with XhoI and EcoRI and ligated into pPIC9 vector (Invitrogen, Leek, The Netherlands). The resulting construct encoded a two-amino acid connecting peptide between the A- and B-chain (Pro(B27)-Thr(B28)Lys-Arg-A), in order to be able to use the conversion strategy described for the corresponding human insulin precursor (13). Following sequence verification the vector was linearised with BglII or SalI and recombined into Pichia pastoris GS115 (Invitrogen). BglII favours recombination into the AOX1 locus of Pichia pastoris resulting in methanol-utilising slow ( $\mathrm{His}^{+} \mathrm{Mut}^{\mathrm{s}}$ ) phenotype transformants. SalI favours recombination into the HIS4 locus resulting in methanol-utilising $\left(\mathrm{His}^{+} \mathrm{Mut}^{+}\right.$) phenotype transformants. Screening for $\mathrm{His}^{+} \mathrm{Mut}^{\mathrm{s}}$ and $\mathrm{His}^{+} \mathrm{Mut}^{+}$ phenotypes was performed on minimal methanol and minimal dextrose agar plates.

\section{Fermentation}

Pichia pastoris was fermented as recommended (14). Biomass was accumulated in buffered glycerol-complex medium in a $15 \mathrm{l}$ glass fermenter at $28^{\circ} \mathrm{C}, 600$ r.p.m. and 1 volume atmospheric air per volume culture per minute, during batch and subsequently fed batch fer-

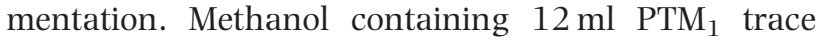
salt/l methanol was used as inducer of the AOX1 promoter, and initiated at a feed rate of $1 \mathrm{ml} / \mathrm{h}$ per litre fermentation volume for the first $2 \mathrm{~h}$ (14). Subsequently the feed rate was increased in $10 \%$ increments every
$30 \mathrm{~min}$ until a final rate of $3 \mathrm{ml} / \mathrm{h}$ per litre fermentation volume. This rate was maintained for the duration of the fermentation, which lasted approximately $70 \mathrm{~h}$. The highest expression levels were obtained at $\mathrm{pH} 5.6$ and the fermentation yield was $8 \mathrm{l}$ of fermentation supernatant with $60 \mathrm{mg} / \mathrm{l}$. At the end of the fermentation the yeast culture was centrifuged twice for $20 \mathrm{~min}$ at $3500 \mathrm{~g}$ at $4^{\circ} \mathrm{C}$. pH was adjusted to 3.5 with sulphuric acid and the supernatant was stored at $-80^{\circ} \mathrm{C}$.

\section{Purification}

Except for reverse-phase (RP)-HPLC all purification steps were performed at $4^{\circ} \mathrm{C}$. Following filtration the supernatant was applied to a RP-C18 Sep-Pak column (Millipore, Hedehusene, Denmark) pretreated with ethanol and $\mathrm{H}_{2} \mathrm{O}$. The column was rinsed in $20 \%(\mathrm{v} / \mathrm{v})$ ethanol and eluted with $60 \%(\mathrm{v} / \mathrm{v})$ ethanol $+0.01 \mathrm{~mol} / \mathrm{l} \mathrm{NaCl}$. The PT proinsulin was then bound to CM cationexchange Sep-Pak columns (Millipore) pretreated with $0.1 \mathrm{~mol} / \mathrm{l}$ sodium acetate, $0.05 \mathrm{~mol} / \mathrm{l} \mathrm{HCl}, 50 \%$ (v/v) ethanol followed by $60 \%(\mathrm{v} / \mathrm{v})$ ethanol. The column was washed with $\mathrm{H}_{2} \mathrm{O}$ and the precursor eluted with $0.1 \mathrm{~mol} / \mathrm{l}$ sodium acetate, $0.05 \mathrm{~mol} / \mathrm{l} \mathrm{HCl}, 50 \%(\mathrm{v} / \mathrm{v})$ ethanol, $0.05 \mathrm{~mol} / \mathrm{l} \mathrm{NaCl}$. The pooled eluted fractions were then adjusted to $\mathrm{pH} 6.5$ with $1 \mathrm{~mol} / \mathrm{l} \mathrm{NaOH}$ and the insulin was precipitated by dilution to $20 \%(\mathrm{v} / \mathrm{v})$ ethanol, addition of $1 / 10$ of the volume of $1 \mathrm{~mol} / \mathrm{l}$ zinc acetate, vortexing and centrifugation for $3 \mathrm{~min}$ at $20000 \boldsymbol{g}$. After resuspension in $\mathrm{H}_{2} \mathrm{O}$ the precursor was purified by RP-HPLC (Hewlett Packard series 1100 with Vydac RP C4 columns $300 \AA$, $5 \mu, 4.6 \times 250$ mm and $10 \times 250 \mathrm{~mm}$; Hewlett Packard, Birkerød, Denmark) using isocratic (20\% (v/w) A for $8 \mathrm{~min})$ and gradient run $(1 \% \mathrm{~B} / \mathrm{min}$ for $20 \mathrm{~min})$ with $0.1 \%(\mathrm{v} / \mathrm{w})$ trifluoracetic acid (TFA) in $\mathrm{H}_{2} \mathrm{O}$ (solvent $\mathrm{A}$ ) and $0.07 \%$ (v/w) TFA in $\mathrm{CH}_{3} \mathrm{CN}$ (solvent B) at $30^{\circ} \mathrm{C}(15,16)$. The purification procedure resulted in a yield of approximately $50 \%$ of PT insulin precursor corresponding to $10 \%$ loss/step. Edman degradation was performed on an Applied Biosystems 476 A Protein Sequenator (Applied Biosystems, Cambridge, Cambs, UK). Matrix assisted laser desorption/ionisation time-of-flight mass spectroscopy (MALDI-TOF MS) was performed on a Biflex mass spectrometer (Bruker, Daltonik, Bremen, Germany) using $\alpha$-cyano-4-hydroxy-cinnamic acid as matrix. It confirmed 40 amino acid residues (Phe (B1) to Thr (A8)) corresponding to $75 \%$ of the protein. By MALDI-TOF (ProB27, ThrB28)-Lys-Arg-A was determined to $6073 \pm 6 \mathrm{Da}$ compared with the calculated 6074 Da (molecular mass calculations were performed using the General Protein Mass Analysis for Windows program from Lighthouse Data, Odense, Denmark).

\section{Confirmation of correct disulphide bonding}

PT insulin precursor was cleaved with endoproteinase Glu-C (Boehringer Mannheim, Hørsholm, Denmark) 
to confirm correct disulphide bonding. At the condition chosen endoproteinase Glu-C cleaves at the carboxylic side of Glu releasing fragments of 2972.0, 1377.9 and 1800.5 Da (containing disulphide bonds Cys (A7)-Cys (B7)), Cys (A20)-Cys (B19) and fragment Arg (B22)-Glu (A4) without a disulphide bond respectively). In a total volume of $130 \mu \mathrm{l}, 5 \mathrm{nmol}(1 \%) \mathrm{PT}$ insulin in a $0.2 \mathrm{~mol} / \mathrm{I} \mathrm{NH}_{4} \mathrm{HCO}_{3}$ buffer $\mathrm{pH} 7.8$ was digested at $37^{\circ} \mathrm{C}$ for $1 \mathrm{~h}$ with $0.1 \%$ endoproteinase Glu-C diluted in $10 \mathrm{mmol} / \mathrm{I} \mathrm{CaCl}_{2}$. The three expected fragments were all detected with the measured values: $2969 \pm 3, \quad 1378 \pm 1.4$ and $1799 \pm 1.8 \mathrm{Da}$ respectively.

\section{Conversion of PT proinsulin to PT insulin}

Twelve milligrams of purified (ProB27, ThrB28)-LysArg-A insulin were digested at $4{ }^{\circ} \mathrm{C}$, in the presence of $213 \mu \mathrm{g}$ sequencing grade trypsin (gift from NovoNordisk, Bagsværd, Denmark) in a total volume of $840 \mu \mathrm{l} \mathrm{H}_{2} \mathrm{O}$ adjusted to $\mathrm{pH}$ 9.5. The reaction was stopped after $5 \mathrm{~h}$ by addition of $20 \mu \mathrm{l} 4 \mathrm{~mol} / \mathrm{l} \mathrm{HCl}$. The product was HPLC purified and lyophilised. (ProB27, ThrB28)-Lys-Arg A was further digested to (PT)-insulin in a total volume of $2400 \mu \mathrm{l}(5 \mathrm{mg} / \mathrm{ml})$ in $50 \mathrm{mmol} / \mathrm{l}$ Tris-HCl, pH 9.3 using $5 \mu \mathrm{g} / \mathrm{ml}$ carboxypeptidase B (Boehringer Mannheim) for $30 \mathrm{~min}$ at $37^{\circ} \mathrm{C}$. The reaction was stopped by acidification with $1 \mathrm{~mol} / \mathrm{l} \mathrm{HCl}$ and the sample was purified by RP-HPLC (13). Iodination of the insulin was performed using $\mathrm{KIO}_{4}$ as described (17). The efficiency of the trypsin and carboxypeptidase B digestion was 75 and $98 \%$. By MALDI-TOF the correct reaction products were confirmed (experimental vs calculated molecular mass): (ProB27, ThrB28)-LysArg A: 6093 6 vs 6092 Da and (ProB27, ThrB28) A: $5806 \pm 6$ vs 5808 Da.

\section{Receptor binding assay}

Human insulin receptors and insulin-like growth factor-I (IGF-I) receptors were purified from transfected baby hamster cells stably expressing these receptors and incubated with ${ }^{125}$ I-human insulin (or ${ }^{125}$ I-IGF-I) and increasing concentrations of unlabelled PT insulin in a total volume of $200 \mu \mathrm{l}$ (containing $100 \mathrm{mmol} / \mathrm{l}$ Hepes $\mathrm{pH} 7.8,100 \mathrm{mmol} / \mathrm{l} \mathrm{NaCl}, 10 \mathrm{mmol} / \mathrm{l} \mathrm{MgSO}_{4}$, $0.5 \%$ human serum albumin, $0.2 \%$ gamma globulin, $0.025 \%$ Triton X-100) for $16 \mathrm{~h}$ at $4{ }^{\circ} \mathrm{C}$. Subsequently, bound insulin tracer was precipitated with $400 \mu \mathrm{l}$ $25 \%$ polyethylene glycol 8000 , and the radioactivity in the pellet was counted by gamma counting $(18,19)$.

\section{Growth-promoting activity of insulin}

CHO-K1 cells were kindly donated by Novo-Nordisk. They were received in passage 4 and used in passages 5-9. They were grown in 90\% Ham F12 medium (Bio-Whittaker Europe, Verviers, Belgium) supplemented with $10 \%$ fetal calf serum (Biological Industries, Kibbutz Beit, Haemek, Israel) and split 1:3 during passage. For assay they were seeded at $60 \%$ confluency in 96-well plates (Greiner Labortechnik $\mathrm{GmbH}$, Frickenhausen, Germany) and left overnight to plate. The cells were then starved for $24 \mathrm{~h}$ in serum-free Ham's F12 medium containing $5 \mu \mathrm{g} / \mathrm{ml}$ apo-transferrin (AppliChem $\mathrm{GmbH}$ ), $20 \mathrm{ng} / \mathrm{ml}$ human insulin (Actrapid; Novo-Nordisk), $5 \mu \mathrm{mol} / \mathrm{I} \mathrm{FeSO}_{4}$ (Fluka, Buchs, Switzerland), $1 \times$ non-essential amino acids and $1 \times$ pyruvate (Gibco, Gaithersburg, MD, USA) and 0.05\% albumin (Sigma A7877; Sigma, St Louis, MO, USA). New starvation medium containing insulin in concentrations $0.1-2000 \mathrm{ng} / \mathrm{ml}$ was added and left on the cells for $18 \mathrm{~h}$. The medium was replaced with similar medium containing $37 \mathrm{MBq} / \mathrm{ml}\left[{ }^{3} \mathrm{H}\right]$ thymidine $\quad(53 \mathrm{Ci} / \mathrm{mmol}$, Amersham) and the cells were harvested in a cell harvester (Automash 2000; Dynex Technologies, Westbart Ltd, Billingshurst, West Sussex, UK) $3 \mathrm{~h}$ later. One millilitre of scintillation fluid (OptiPhase 'HiSafe' 3; Pharmacia LKB, Uppsala, Sweden) was added to each glass filter and the samples were counted in a Tri-carb 1600 TR scintillation counter (Packard Canberra, Inc., Meriden, CT, USA).

\section{Disappearance of insulin from pig subcutis}

Female, non-diabetic, conscious pigs crossbred from Danish Landrace and Yorkshire with an average body weight of $94.7 \mathrm{~kg}$ were fasted overnight, then injected s.c. into the neck region with $60 \mu \mathrm{l}$ sterile PT insulin and (contralaterally) with human insulin. The insulins were formulated as: $0.6 \mathrm{mmol} / \mathrm{l}$ insulin, $2 \mu \mathrm{Ci}{ }^{125} \mathrm{I}-\mathrm{PT}$ or ${ }^{125} \mathrm{I}$-human insulin $/ \mathrm{ml}, 1.6 \%$ glycerol, $0.3 \% \mathrm{~m}$ cresol, $0.25 \mathrm{mmol} / \mathrm{l}$ zinc acetate (2.5 zinc/hexamer), $13 \mathrm{mmol} / \mathrm{l}$ phosphate buffer, $\mathrm{pH}$ 7.3. The disappearance was followed for $6 \mathrm{~h}$ by external $\gamma$-counting over the injection sites. Each experiment was carried out in five different pigs $(19,20)$.

\section{Testing of blood glucose lowering effect}

Balb/c mice (Bomholtgård, Ry, Denmark), 8-10 weeks of age, weighing approximately $30 \mathrm{~g}$ were used for in vivo testing of insulin blood glucose lowering activity. The mice were fed freely and had free access to chow and water before and during the experiment. One hundred microlitres of insulin preparation per $10 \mathrm{~g}$ body weight were injected s.c. in the neck fold, and tail capillary blood glucose was measured at 10 min intervals for 60 min using a blood glucose meter (Bayer, Leverkusen, Germany). The insulin preparations were verified by HPLC prior to injection and contained: 3.7 and $5.55 \mu \mathrm{g} / \mathrm{ml}$ recombinant human insulin (Novolin; Novo-Nordisk) and $3.7 \mu \mathrm{g} / \mathrm{ml} \mathrm{PT}$ insulin in isotonic sodium chloride adjusted to $\mathrm{pH} 4.0$ containing $0.05 \%$ BSA. All animal work was carried out under the regulations set by the Animal Experiments Inspectorate. 


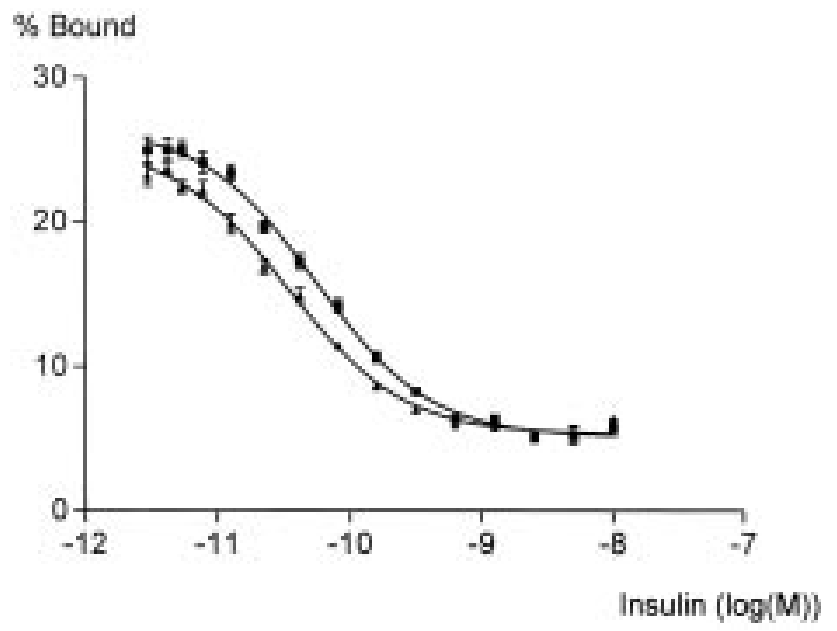

Figure 1 Displacement of ${ }^{125} \mathrm{I}$ human insulin from human insulin receptor by human insulin $(\boldsymbol{\square})$ and PT insulin $(\boldsymbol{\Delta})$. The curves display the results of three independent experiments in dublicates. The error bars display means \pm S.E.M.

\section{Results}

\section{Receptor binding assay}

To evaluate the affinity of PT insulin for the human insulin receptor and for the IGF-I receptor, binding assays were performed using human insulin as a reference (Fig. 1). The results demonstrated that the affinity of PT insulin was $159 \%$ of that of human insulin for the human insulin receptor $\left(K_{\mathrm{d}} \quad \mathrm{PT}=3.48 \times\right.$ $10^{-11} \mathrm{~mol} / \mathrm{l}, K_{\mathrm{d}}$ human insulin $=5.5 \times 10^{-11} \mathrm{~mol} / \mathrm{l}$ ). This result confirms that the PT insulin has preserved insulin receptor binding as hypothesised. The affinity for the IGF receptor was also measured since stimulation of this receptor could exclude the use of PT insulin from clinical use. The affinity of the PT insulin was found to be approximately 4-fold higher $\left(K_{\mathrm{d}}=\right.$ $\left.3.4 \times 10^{-8} \mathrm{~mol} / \mathrm{l}\right)$ than the affinity of human insulin $\left(K_{\mathrm{d}}=1.3 \times 10^{-7} \mathrm{~mol} / \mathrm{l}\right)$.

\section{DNA synthesis activity}

Following $24 \mathrm{~h}$ of serum starvation and $18 \mathrm{~h}$ of insulin stimulation, DNA synthesis was evaluated during $3 \mathrm{~h}$ of thymidine incorporation. As reference we used human insulin, HPLC purified from a commercial preparation. The following concentrations were used: $0,0.1,0.6,3$, 16, 80, 400 and $2000 \mathrm{ng} / \mathrm{ml}$. As seen in Fig. 1, PT insulin was slightly more active $(28-46 \%)$ in intermediate concentrations than human insulin. Part of the stimulation can probably be attributed to the inclusion of a minor HPLC variant form of PT insulin believed to be deamidated insulin with the main fraction. It is expected that this form is biologically active and therefore contributes an approximately 4\% increase in insulin concentration. However, the majority of the observed stimulation probably reflects receptor stimulation caused by the slightly higher IGF receptor binding affinity found for PT insulin.

\section{Disappearance of PT insulin from pig s.c. tissue}

PT insulin was initially absorbed at the same rate as human insulin until about $75 \%$ of the radioactivity remained; PT insulin then showed accelerated absorption

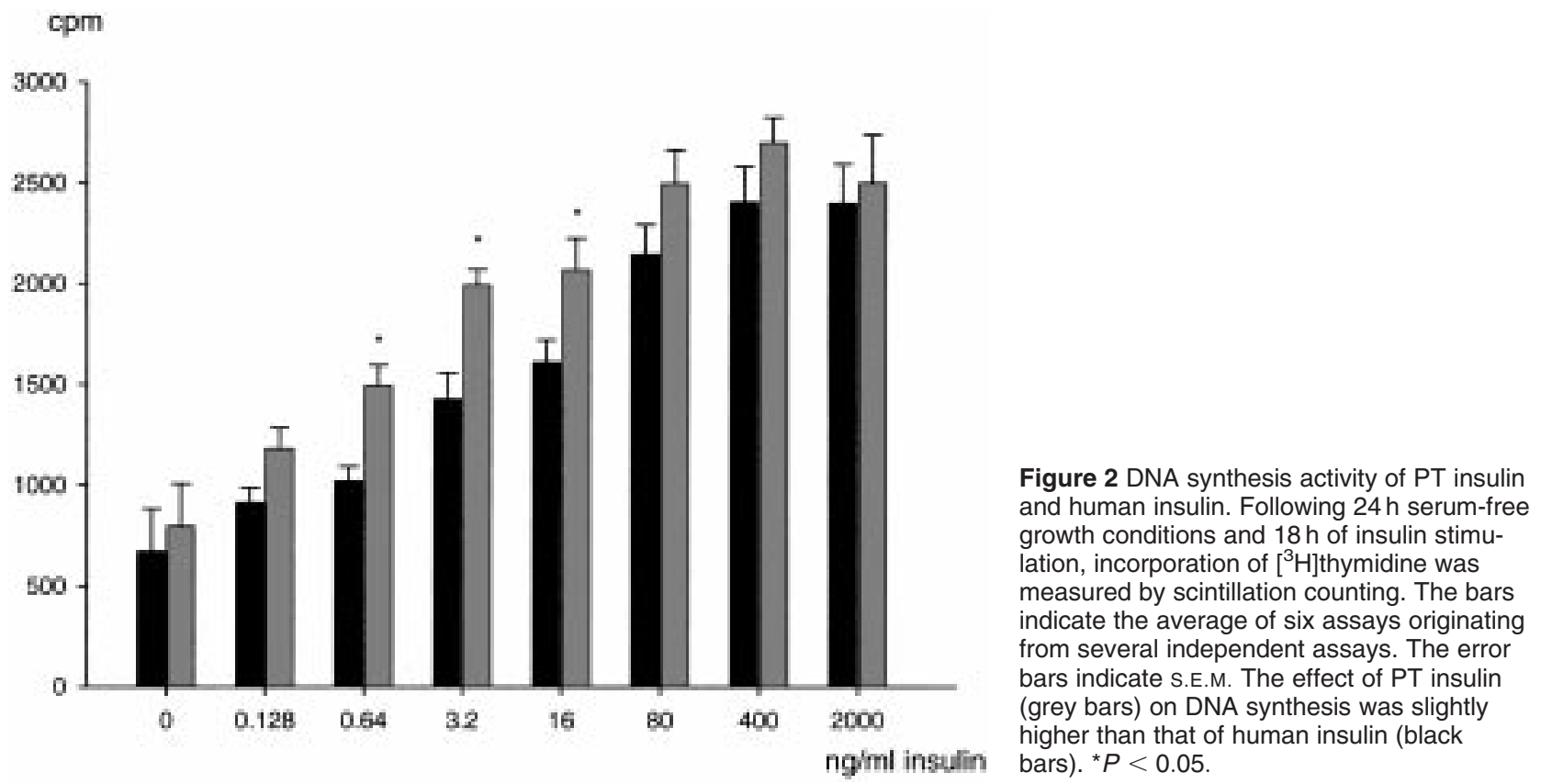

www.eje.org 


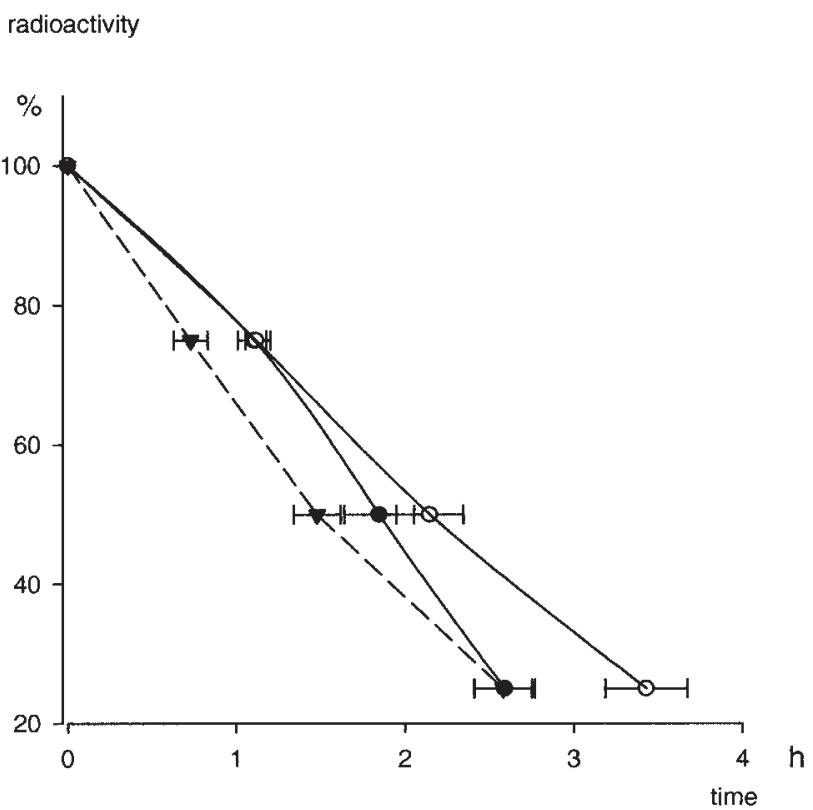

Figure 3 Disappearance of iodinated insulins from subcutis following injection in the neck region in pigs. Mean \pm S.E.M. residual radioactivity is indicated following s.c. injection of $60 \mu \mathrm{l} 0.6 \mathrm{mmol} / \mathrm{l}$ ${ }^{125}$ I-labelled zinc-insulin formulations $(\bullet, P T$ insulin; $\bigcirc$, human insulin). Five pigs were used in each experiment. For comparison the Asp (B28) absorption profile ( $\mathbf{\nabla}$ ) was inserted from previous recordings (22).

relative to human insulin (Fig. 3). The time for reaching $25 \%$ remaining activity was significantly shorter for PT insulin than for human insulin $(2.59 \pm 0.17$ vs $3.43 \pm 0.24 \mathrm{~h}, n=4, P=0.03)$. For comparison the absorption profile of Asp (B28) is shown. The data were obtained in separate experiments as only two insulins could be tested simultaneously (21). It is seen that PT insulin is not absorbed as rapidly as Asp (B28), especially initially (75\% remaining activity is reached at $0.73 \pm 0.1 \mathrm{vs} 1.11 \pm 0.1 \mathrm{~h}$ ).

\section{The blood glucose lowering effect of PT insulin}

The potency of insulin is often evaluated using the twin crossover design (22). However, this has been shown to fail in experiments where two different insulins are compared (23). The insulin effect was therefore evaluated from the integral of the blood glucose curve from 0 to $20 \mathrm{~min}$ or from 0 to $60 \mathrm{~min}$ following s.c. injection. An approximate value was obtained by calculating the area of the polygon enclosed by the curve. As shown in Fig. 4, PT insulin had a larger blood glucose lowering effect than human insulin when injected in equimolar amounts both when evaluated for 0-20 min (integral: $22.9 \pm 3.9$ vs $13.9 \pm 0.61, n=6, P=0.049)$ and when evaluated for $0-60 \mathrm{~min}$ (integral: $61.4 \pm 7$ vs $30 \pm 4$, $n=6, P=0.046)$. When the injection of human insulin was repeated using a $50 \%$ increased dose the blood glucose effect was similar to PT insulin (integral ${ }_{0-60}$ : $57.7 \pm 9$ vs $61.4 \pm 7, n=6, P=0.76)$.

\section{Discussion}

We successfully designed, fermented, processed and purified human PT insulin using methylotrophic yeast as an expression system. As expected, the insulin variant retained its full receptor binding and blood glucose lowering activity and showed accelerated disappearance from pig s.c. tissue compared with human insulin, indicating accelerated absorption.

Absorption of insulin in tissue is critically dependent on several parameters including animal species, site of

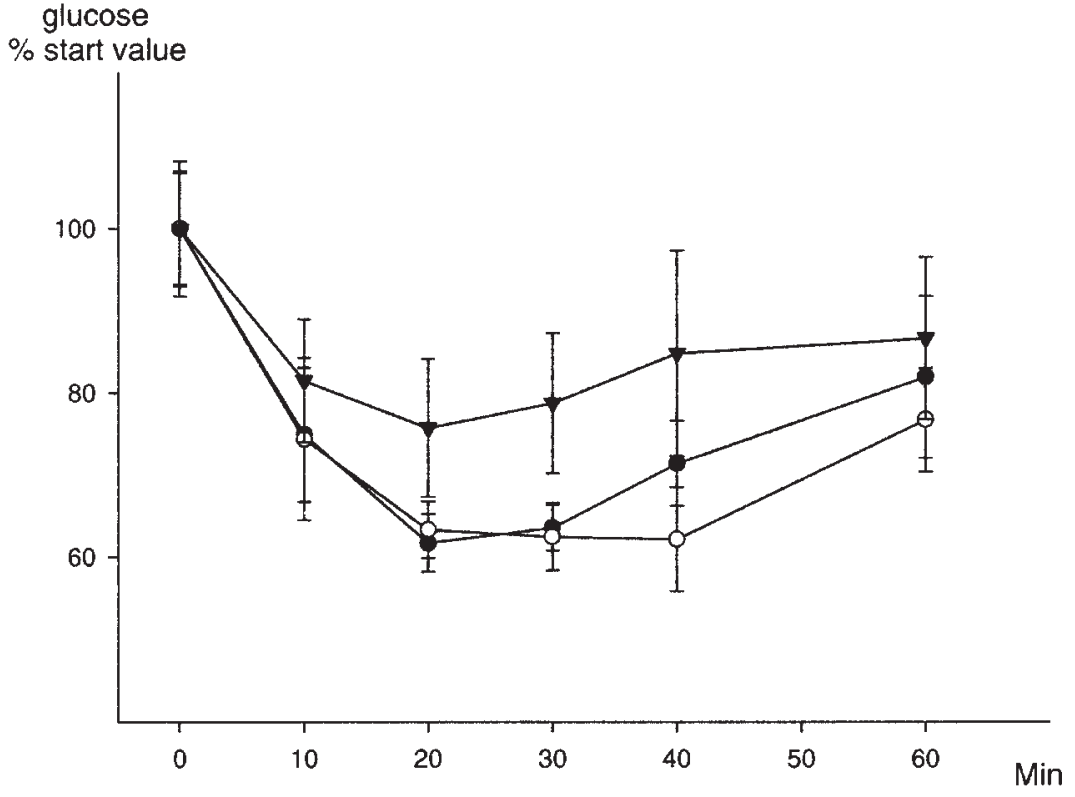

Figure 4 Testing of blood glucose lowering effect of insulin PT and human insulin in mice. Following s.c. injection the blood glucose was measured for $60 \mathrm{~min}$. The blood glucose lowering effect of PT insulin (•) was compared with equal $(\boldsymbol{\nabla})$ or $50 \%$ increased dose $(O)$ of human insulin. Each curve represents the average of six animals and is normalised according to the initial blood glucose value (means \pm S.E.M.). 
injection, $\mathrm{pH}$, salts, concentration and presence of zinc ions. Pigs are considered the best animal model, since the s.c. tissue is similar to human subcutis (20). The pharmacological conditions were carefully chosen to exactly match commercial insulin preparations. We can therefore exclude that the observed difference in disappearance can be attributed to factors other than the insulin itself.

We observed that the increase in disappearance was not seen immediately after the injection and that it was less accelerated than for Asp (B28) (3, 24). We suggest that this could be due to only partial disruption of the intermolecular interactions. This would allow insulin to form hexamers in the presence of zinc and account for the accelerated absorption from subcutis following diffusion of zinc ions from the injection site. Asp (B28) which has also been stabilised with zinc likewise aggregates in pharmacological preparations but dissociates immediately when injected, resulting in fast disappearance from subcutis (25). A faster absorption of PT insulin can probably be obtained if formulated in the absence of zinc, but it is likely that other means of stabilising the preparation must then be considered to prevent fibrillation (26).

The receptor binding assay confirmed that the human insulin receptor binding site was not impaired by interchanging Thr (B27) and Pro (B28). A small increase in affinity for the IGF-I receptor was also seen but is not expected to pose a problem for the use of the insulin variant clinically, since the receptor binding affinity is still approximately 800-fold lower for insulin than for IGF-I $\left(K_{\mathrm{d}}=4.4 \times 10^{-11} \mathrm{~mol} / \mathrm{l}\right)$. Receptor specificity and activation are important characteristics of insulins since some insulin analogues in the past have been shown to possess increased growth hormone activity, leading to carcinogenesis (27). We found a $28-46 \%$ increase in DNA synthesis induction of PT insulin over human insulin. Although increased, the magnitude is far lower than other analogues that stimulate DNA synthesis up to 600-fold (28). The modest increase found for PT insulin does not, therefore, raise concern for therapeutic use, especially since PT insulin is more potent than human insulin and smaller doses are therefore required.

The blood glucose lowering effect of PT insulin was approximately 50\% higher than that of human insulin, which is in agreement with the higher binding affinity of PT insulin for the insulin receptor. This suggests that PT insulin has higher intrinsic receptor activation than human insulin. Although this finding should be verified in the human system, variations in the intrinsic insulin receptor stimulation activity are not uncommon, even for insulins with similar binding characteristics (29).

Recent nuclear magnetic resonance investigations have shown that the B-chain of PT insulin is exceptionally flexible and structureless (30). This supports the hypothesis that partial unfolding of this part of the molecule is needed for binding and activation of the receptor. The discovery can possibly help further dissection of the insulin receptor function. If $\mathrm{PT}$ insulin has easier access to receptor activation than human insulin it is also possible that PT insulin could be used clinically in a small group of type 2 diabetes patients who do not respond to normal insulin due to insulin receptor mutations.

\section{Acknowledgements}

We thank the following Novo-Nordisk staff: Lauge Schäffer for receptor binding experiments, Lars Thim, for various materials and advice, Per Balschmidt and Anne Plum for making the in vivo experiments in pigs possible and Anders Sørensen for CHO-K1 cells. We also thank Svend Olav Andersen, University of Copenhagen for amino acid sequencing and mass spectrometry and Bo Jensen, University of Copenhagen, for lending fermentation equipment. The study was supported by the Velux Foundation, Copenhagen, Denmark.

\section{References}

1 Blundell TL, Dodson G, Hodgkin DC \& Mercola D. Insulin: the structure in the crystal and its reflection in chemistry and biology. Advances in Protein Chemistry 197226 280-402.

2 Brange J, Owens DR, Kang S \& Vølund A. Monomeric insulins and their experimental and clinical implications. Diabetes Care 1990 13 923-954.

3 Brange J, Ribel U, Hansen JF, Dodson G, Hansen MT, Havelund S et al. Monomeric insulins obtained by protein engineering and their medical implications. Nature 1988333 679-682.

4 Brems DN, Alter LA, Beckage MJ, Chance RE, DiMarchi RD, Green LK et al. Altering the association properties of insulin by amino acid replacement. Protein Engineering 19925 527-533.

5 Weiss MA, Hua QX, Lynch CS, Frank BH \& Shoelson SE. Heteronuclear 2D NMR studies of an engineered insulin monomer: assignment and characterization of the receptor-binding surface by selective ${ }^{2} \mathrm{H}$ and ${ }^{13} \mathrm{C}$ labeling with application to protein design. Biochemistry $1991307373-7389$.

6 Plum A, Agersø H \& Andersen L. Pharacokinetics of the rapidacting insulin analog, insulin aspart, in rats, dogs, and pigs, and pharmacodynamics of insulin aspart in pigs. Drug Metabolism and Disposition: the Biological Fate of Chemicals 200028 155-160.

7 Mudaliar SR, Lindberg FA, Joyce M, Beerdsen P, Strange P, Lin A et al. Insulin aspart (B28 asp-insulin): a fast-acting analog of human insulin: absorption kinetics and action profile compared with regular human insulin in healthy nondiabetic subjects. Diabetes Care 199922 1501-1506.

8 Bolli GB, Di Marchi RD, Park GD \& Koivisto VA. Insulin analogues and their potential in the management of diabetes mellitus. Diabetologia 199942 1151-1167.

9 Baker EN, Blundell TL, Cutfield JF, Cutfield SM, Dodson EJ, Dodson GG et al. The structure of $2 \mathrm{Zn}$ pig insulin crystals at $1.5 \AA$ resolution. Philosophical Transactions of the Royal Society of London. Series B: Biological Sciences 1988319 369-456.

10 Pocker Y \& Biswas SB. Self-association of insulin and the role of hydrophobic bonding: a thermodynamic model of insulin dimerization. Biochemistry 198120 4354-4361.

11 Jørgensen AM, Olsen HB, Balschmidt P \& Led JJ. Solution structure of the superactive monomeric des-[Phe (B25)] human insulin mutant: elucidation of the structural basis for the monomerization 
of des-[Phe (B25)] insulin and the dimerization of native insulin. Journal of Molecular Biology 1996257 684-699.

12 Gammeltoft S. Insulin receptors: binding kinetics and structurefunction relationship of insulin. Physiological Reviews $1984 \mathbf{6 4}$ 1321-1378.

13 Thim L, Hansen MT, Norris K, Hoegh I, Boel E, Forstrom J et al. Secretion and processing of insulin precursors in yeast. PNAS $1986836766-6770$.

14 Invitrogen. Pichia Expression Kit - a Manual of Methods for Expression of Recombinant Proteins in Pichia pastoris. Version 30, catalog no. K1710-01.

15 Dimov N \& Simeonov S. Experimental models for optimization of insulin separation on reversed phase columns. Biomedical Chromatography 19948 32-36.

16 Klyushnichenko VE, Yakimov SA, Arutyunyan AM, Ivanov AE Maltsev KV \& Wulfson AN. Recombinant human insulin. V. Optimization of the reversed-phase high-performance liquid chromatographic separation. Journal of Chromatography. B, Biomedical Sciences and Applications $1994662363-369$.

17 Jorgensen KH \& Larsen UD. Homogeneous mono-(125)I-insulins. Preparation and characterization of mono-(125)I-(tyr a14)- and mono-(125)I-(tyr a19)-insulin. Diabetologia 198019 546-554.

18 Andersen AS, Kjeldsen T, Wiberg FC, Vissing H, Schäffer L, Rasmussen JS et al. Identification of determinants that confer ligand specificity on the insulin receptor. Journal of Biological Chemistry 1992267 13681-13686.

19 Markussen J, Damgaard U, Jorgensen KH, Sorensen E \& Thim L. Human monocomponent insulin. Chemistry and characteristics. Acta Medica Scandinavica 1983671 (Suppl) 99-105.

20 Ribel U, Jorgensen KH, Brange J \& Henriksen U. The pig as a model for subcutaneous insulin absorption in man. In Diabetes, Proceedings of the 12th Congress of the International Diabetes Federation, Madrid 1985, pp 891-896. Eds M Serrano-Rios \& PJ Lefebvre. Amsterdam: Excerpta Medica, 1986.

21 Plum A. S.c. disappearance and PK/PD study in pigs of soluble phases of ${ }^{125} \mathrm{I}$ - (Tyr A14) labelled insulin aspart biphasis 30 , $3.5 \mathrm{Zn} /$ hexamer (mannitol formulation) and HM PenMix 30, 3.5 Zn/hexamer. Pharmacokinetic Report No. 26, Health Care
Business, Preclinical Development, Pharmacokinetics Department, Insulin Aspart, Study No 950475, Novo Nodisk A/S, Denmark $19979504751-29$.

22 Pharmacopial Nord. 1973 IV 71b-72b.

23 Vølund A, Pingel M \& Sørensen E. Differential potency of pork and beef insulins in the USP rabbit bioassay system. In Hormone Drugs: United States Pharmacopeial Convention, Rockville, Maryland, pp 208-225. Eds JL Gueriguian, ED Bransome \& AS Outshoorn. 1982.

24 Kang S, Brange J, Burch A, Volund A \& Owens DR. Absorption kinetics and action profiles of subcutaneously administered insulin analogues (AspB9GluB27, AspB10, AspB28) in healthy subjects. Diabetes Care 199114 1057-1065.

25 Whittingham JL, Edwards DJ, Antson AA, Clarkson JM \& Dodson GG. Interactions of phenol and $m$-cresol in the insulin hexamer, and their effect on the association properties of B28 Pro $\rightarrow$ Asp insulin analogues. Biochemistry 199837 11516-11523.

26 Brange J, Andersen L, Laursen ED, Meyn G \& Rasmussen E. Toward understanding insulin fibrillation. Journal of Pharmaceutical Sciences $199786517-525$.

27 Pollak M. Insulin-like growth factor physiology and cancer risk. European Journal of Cancer 200036 1224-1228.

28 Hansen BF, Danielsen GM, Drejer K, Sørensen AR, Klein HH \& Lundemose AG. Sustained signalling from the insulin receptor after stimulation with insulin analogues exhibiting increased mitogenic potency. Biochemical Journal $1996315271-279$.

29 Ribel U, Hougaard P, Drejer K \& Sørensen AR. Equivalent in vivo biological activity of insulin analogues and human insulin despite different in vitro potencies. Diabetes 199039 1033-1039.

30 Keller D, Clausen R, Josefsen K \& Led JJ. Spectroscopic investigation of the solution structure and folding of an unusually flexible human insulin mutant with increased biological activity. Biochemistry 200140 10732-10740.

Received 12 July 2001

Accepted 2 May 2002 